\title{
A Importância da Qualidade do Ar Interior na Pandemia de COVID-19
}

\section{The Importance of Indoor Air Quality in the COVID-19 Pandemic}

\author{
Manuel GAMEIRO DA SILVA $\square^{1}$ \\ Acta Med Port 2021 Dec;34(12):805-806 - https://doi.org/10.20344/amp.17437
}

Palavras-chave: COVID-19; Poluição do Ar em Ambientes Fechados; SARS-CoV-2

Keywords: Air Pollution, Indoor; COVID-19; SARS-CoV-2

A qualidade do ar interior (QAI) e a ventilação são temas sobre os quais nos habituámos a ouvir falar com muito mais frequência nos últimos tempos, devido à pandemia de COVID-19. Tendo em conta que o contágio se verifica sobretudo pela emissão de vírus por uma pessoa infetada através da exalação e à sua posterior inalação por um recetor suscetível, é fácil de perceber que a forma como é gerida a QAI nos edifícios pode ter uma grande influência na maior ou menor disseminação da doença.

Os três modos de transmissão de doenças infeciosas por via aérea estão relacionados com a dimensão das gotículas de água que, fazendo parte do escoamento de exalação na respiração, transportam para o exterior do corpo humano os microrganismos patogénicos existentes nos órgãos do sistema respiratório de uma pessoa infetada. Assim, as gotículas têm, após a sua exalação, trajetórias diferentes no ar, fruto das relações que, em função do seu tamanho, podem ocorrer entre as forças aerodinâmicas e gravíticas a que estão sujeitas. , $^{1,2}$ Estes comportamentos diferentes estão associados a três classes estabelecidas em função do diâmetro das gotículas e correspondem aos modos de transmissão definidos respetivamente como por contato, por gotículas e por aerossóis. As gotículas de maior dimensão (diâmetro > $50 \mu \mathrm{m}$ ) caem a distâncias, medidas relativamente à boca do emissor, tipicamente inferiores a um metro, as de dimensão intermédia $(10 \mu \mathrm{m}$ < diâmetro < $50 \mu \mathrm{m})$ a distâncias entre um e dois metros, ficando as de menor dimensão (diâmetro < $10 \mu \mathrm{m}$ ) em suspensão no ar por períodos temporais que podem atingir várias horas.

No início da pandemia, a Organização Mundial de Saúde (OMS) difundiu informação em que hierarquizava os papéis que cada modo de transmissão teria na propagação da doença, considerando como realmente importantes os modos de gotículas e contacto, e praticamente irrelevante o modo de transmissão por aerossóis. Esta posição inicial da OMS resultou provavelmente, por um lado, da escassez de casos reportados de transmissão viral por aerossóis até ao início da pandemia COVID-19 e, por outro, dos resultados que se conhecem quanto à distribuição de probabilidades da emissão de gotículas em função do seu tamanho na fase de exalação - em que um pouco mais de metade das partículas têm dimensão superior a $10 \mu \mathrm{m}$. Como se sabe, a capacidade de transportar vírus no interior das gotículas está associada ao seu volume e não à sua dimensão caraterística linear (por exemplo uma gotícula de $100 \mu \mathrm{m}$ de diâmetro poderá transportar 1000 vezes mais vírus do que uma de $10 \mu \mathrm{m}$ ), dado que essa é a relação dos seus volumes, pelo que a probabilidade de existência de carga viral potencialmente perigosa é muito mais elevada nas partículas de maior dimensão.

No entanto, a questão da transmissão desde o doente infetado até ao recetor sensível não pode ser analisada só a partir das probabilidades associadas à fase da emissão das gotículas. Decompondo uma linha de transmissão, desde a sua origem até ao seu destino, é possível identificar as fases e produção de vírus no interior do corpo do emissor, emissão, transporte e persistência, receção e infeção. No caso do vírus SARS-CoV-2 há uma grande diferença relativamente a outras epidemias, como por exemplo a do SARS-1, na fase inicial designada como produção. Nesta etapa, durante a qual o vírus se multiplica no interior do corpo de uma pessoa infetada, as colónias geradas no caso do SARS-CoV-2 são cerca de 1000 vezes mais numerosas, de acordo com os resultados publicados pelo Laboratório de Microbiologia de Bundeswehr em abril de 2020. ${ }^{3}$ Uma tal carga viral passa a ser suficientemente forte nos aerossóis, constituídos pelas gotículas de menor dimensão em suspensão no ar, para provocar a ocorrência muito mais frequente de situações em que a dose de exposição fica acima do chamado limiar de infecciosidade. ${ }^{4}$ Ao longo da evolução da pandemia, as variantes que persistiram foram aquelas que demonstraram ter uma maior capacidade para se multiplicar e, consequentemente, taxas de propagação da doença infeciosa mais elevadas, como é o caso da denominada variante Delta.

Nestas circunstâncias, durante a fase da receção - que corresponde à inalação do recetor sensível - as probabilidades do modo de transmissão por aerossóis são mais

1. Departamento de Engenharia Mecânica. Associação para o Desenvolvimento da Aerodinâmica Industrial. Faculdade de Ciências e Tecnologia da Universidade Coimbra. Coimbra. Portugal.

$\square$ Autor correspondente: Manuel Gameiro da Silva. manuel.gameiro@dem.uc.pt

Recebido: 02 de novembro de 2021 - Aceite: 03 de novembro de 2021 - Online issue published: 02 de dezembro de 2021 Copyright $\odot$ Ordem dos Médicos 2021 
elevadas do que as dos outros dois modos, e ele pode tornar-se dominante. ${ }^{4}$ É muito mais fácil inalar partículas em suspensão do que gotículas em trajetória direta entre o emissor e o recetor ou de gotas depositadas numa superfície, transportadas por alguém que tocou exatamente no local onde estava essa gota e que trouxe essa zona contaminada da mão à face, junto ao nariz ou à boca, no preciso momento da inalação.

No caso da transmissão através dos aerossóis, não há distância de segurança entre o emissor e o recetor porque os núcleos das gotículas que restam após a evaporação inicial da fase líquida ficam com dimensões tão pequenas que podem permanecer em suspensão por horas - e serem depois arrastados pelos fluxos de ar podendo distribuir-se espacialmente por todo o compartimento em causa. Assim, para diminuir o risco de transmissão através deste modo é recomendado o uso de máscaras e a utilização de processos que diminuam a concentração da carga viral em suspensão no ar (por outras palavras, que melhorem a QAI), tais como a extração localizada, a ventilação e a purificação/limpeza do ar. ${ }^{5,6}$ A seleção do processo a utilizar depende da fonte contaminante, sendo a extração destinada a situações em que há fontes intensas com localização fixa e a ventilação a fontes múltiplas de localização desconhecida ou aleatória. A limpeza ou purificação do ar, além de ser um processo que se pode usar de forma complementar relativamente a cada um dos outros, é particularmente importante para melhorar a qualidade do ar exterior antes de o utilizar na diluição da concentração de contaminantes no interior dos edifícios.

Convém aqui referir que o que determina a probabilidade de contrair uma infeção por via aérea é a dose de contaminante inalada ao longo do período de exposição. A dose, para um dado contaminante, é o valor, expresso nas unidades utilizadas para quantificar a sua existência no ar ambiente, acumulado ao longo de um dado tempo. Pode ser calculada a partir do produto da concentração média durante a exposição pelo tempo de duração dessa exposição. Uma forma radical de diminuir drasticamente a dose média inalada numa grande população é o confinamento porque, ao diminuir a probabilidade de exposição da generalidade das pessoas a ambientes com ocupação múltipla e numerosa, a carga viral a que elas estão sujeitas toma valores mais baixos.

É possível implementar estratégias de gestão do risco de transmissão baseadas, quer em ferramentas de cálcu-

\section{REFERÊNCIAS}

1. Gameiro da Silva M. Analysis of the transmission modes of COVID-19 in light of the concepts of Indoor Air Quality. REHVA J. 2020;03:46-54.

2. Correia G, Rodrigues L, Gameiro da Silva M, Gonçalves T. Airborne route and bad use of ventilation systems as non-negligible factors in SARS-CoV-2 transmission. Med Hypotheses. 2020;141:109781.

3. Wölfel R, Corman V, Guggemos W, Seilmaier M, Zange S, Müller M, et al. Virological assessment of hospitalized patients with COVID-2019. Nature. 2020;581:465-9.

4. Morawska L, Milton D K It Is Time to Address Airborne Transmission of Coronavirus Disease 2019 (COVID-19). Clin Infect Dis. 2020;71:23113.

5. Gameiro da Silva M. Ventilação e qualidade do ar interior. [consultado lo, ${ }^{7}$ quer na monitorização da QAI a partir de poluentes de medição mais fácil, mas com evolução temporal altamente correlacionada com a carga viral, como é o caso do dióxido de carbono de origem metabólica. A aplicação eficaz destas estratégias implica, contudo, um conhecimento detalhado das circunstâncias associadas à situação, qualquer que seja o tipo de ambiente (edifício, meio de transporte, espaço exterior, etc.). A parametrização dos sistemas de ventilação e purificação de ar depende de variáveis tais como as caraterísticas geométricas do espaço, a intensidade das fontes contaminantes, a eficiência dos equipamentos utilizados e a utilização de medidas complementares de proteção. ${ }^{5,6}$

Convém referir que se deve ter o cuidado de evitar que a sugestão de medidas relacionadas com a QAI ocorra de forma vaga e difusa, como quando se diz que os espaços devem estar convenientemente ventilados. Tal como um clínico não recomenda a um doente que tome um medicamento sem indicar a quantidade e forma de administração do mesmo, também um processo de ventilação ou purificação de ar não se deve recomendar de forma não quantificada.

Uma das consequências da pandemia de COVID-19 é que há na comunidade científica (caracterizada pela multidisciplinaridade), entre quem trabalha na QAI de edifícios, a convicção quase unânime de que os requisitos de ventilação e de qualidade do ar interior, que eram definidos sobretudo em função das concentrações de referência de poluentes químicos, terão que passar a ter também em conta, de forma muito mais evidente, os contaminantes biológicos. Por outro lado, estão agora disponíveis, na sequência do esforço científico e de disseminação de conhecimento desenvolvido durante a pandemia, ferramentas de cálculo que permitem modelar de forma fácil os ambientes interiores. o que propicia as condições para uma abordagem precisa e quantificada das situações relacionadas com os processos de ventilação.

\section{CONFLITOS DE INTERESSE}

O autor declara não ter conflitos de interesse relacionados com o presente trabalho.

\section{FONTES DE FINANCIAMENTO}

O presente artigo foi elaborado no âmbito do projeto europeu do programa SUDOE 3SqAir - SOE4/P1/E1004.

2021 nov 01]. Disponível em: https://fundiestamo.com/wp-content/ uploads/2020/07/Guia-FNRE-Fundo-Nacional-de-Reabilitacao-doEdificado.pdf.

6. Federation of European Heating, Ventilation and Air Conditioning Associations. Rehva Covid-19 guidance document, April 15, 2021. How to operate HVAC and other building service systems to prevent the spread of the coronavirus SARS-CoV-2 disease (COVID-19) in workplaces. [consultado 2021 nov 01]. Disponível em: https://www. rehva.eu/activities/covid-19-guidance/rehva-covid-19-guidance.

7. Almeida SM, Sousa J. Modelação da contribuição de fatores influenciadores do risco de infeção por SARS-CoV-2 em ambientes interiores. Acta Med Port. 2021;34:815-25. 